\title{
Upaya Meningkatkan Hasil Belajar Peserta Didik pada Mata Pelajaran IPS Madrasah Ibtidaiyah melalui Metode Gallery Walk
}

\author{
Ai Nurpadilah \\ Institut Agama Islam Darussalam (IAID), Ciamis-Jawa Barat \\ Email: ainurfadilah@gmail.com \\ Udung Hari Darifah \\ Institut Agama Islam Darussalam (IAID), Ciamis-Jawa Barat \\ Dudi \\ Institut Agama Islam Darussalam (IAID), Ciamis-Jawa Barat
}

\begin{abstract}
This study is based on the low learning outcomes of students on IPS subjects. As it is known that the Education Unit Level Curriculum (KTSP) demands complete learning according to the conditions of students and schools, so that in Madrasah Ibtidaiyah Banjarharja has been set Minimum Exhaustiveness Criteria (KKM) for Social Science subjects (IPS) class V of 75. However The circumstances that occur in the field is the result of learning IPS obtained by V grade students about $40 \%$ or 12 students still get the value below the KKM with an average value of 72.25 . Therefore, as an effort to improve learners' learning outcomes, researchers apply learning method gallery walk. The method used in classroom action research (PTK) research model Kurt Lewin. Data collection techniques are observation techniques, test and assessment techniques, and descriptive analysis techniques. After doing research, learning result of learners with the use of gallery walk learning method has increased, that is pre cycle average 72,25 with completeness percentage reach $40 \%$, in cycle I reaching average value 79 with percentage mastery reach $65 \%$, while in the second cycle reached an average value of 83.25 with a percentage of completeness reached $80 \%$, and in the third cycle reached an average value of 89.75 with a percentage of completeness reached $100 \%$. Thus, the learning method gallery walk can improve learning outcomes of learners.
\end{abstract}

Keywords: Social studies learning, learning outcomes, gallery walk

\section{PENDAHULUAN}

Ilmu pengetahuan sosial merupakan salah satu mata pelajaran yang diajarkan di SD/MI. Menurut Sapriya (2006: 4) IPS bagi siswa SD/MI 
berguna untuk mengenal konsep-konsep yang berkaitan dengan kehidupan masyarakat dan lingkungannya. Selain tujuan tersebut, menurut Winataputra (2010:19) IPS juga memiliki tujuan utama yaitu di harapkan peserta didik memiliki kemampuan dasar untuk berpikir logis, kritis, rasa ingin tahu, inquiri, memecahkan masalah dan memiliki keterampilan dalam kehidupan sosial.

Melalui mata pelajaran IPS tersebut peserta didik diarahkan untuk dapat menjadi warga negara Indonesia yang demokratis, bertanggung jawab, serta warga dunia yang cinta damai. Oleh karena itu, seorang guru dituntut harus mampu merancang suatu pembelajaran semaksimal mungkin agar bisa mencapai tujuan pembelajaran.

Pada proses pembelajaran IPS sering dipermasalahkan mengenai materi pelajaran IPS yang cenderung sulit menarik perhatian peserta didik. Hal ini tentu menjadi tantangan bagi guru untuk meningkatkan hasil belajar pada pelajaran tersebut. Salah satu upaya yang ditempuh bagi guru dalam meningkatkan hasil belajar adalah dengan selalu memberi motivasi. Disamping itu, dalam proses belajar mengajar perlu menggunakan metode yang tepat dan efektif agar peserta didik aktif dan merasa senang dalam kegiatan belajar mengajar.

Berdasarkan hasil pengamatan di kelas Madrasah Ibtidaiyah Banjarharja menunjukkan bahwa masih sering dijumpai permasalahan dalam pembelajaran IPS, guru dalam mengajar masih menggunakan metode konvensional yaitu metode ceramah. Karena hal tersebut peserta didik kurang antusias, tidak bersemangat dan cenderung bosan dalam kegiatan belajar mengajar, anak kurang di dorong untuk mengembangkan kemampuan berfikirnya. Proses pembelajaran di kelas lebih menekankan kepada kemampuan anak untuk menghafal informasi. Otak anak di paksa untuk mengingat dan menimbun informasi yang di dengarnya dari guru. Anak tidak di dorong menjadi aktif untuk belajar memecahkan masalah yang berkaitan dengan pembelajaran IPS (Sumber: Hasil pengamatan di kelas Madrasah Ibtidaiyah Banjarharja tanggal 6 April 2017).

Menurut teori pengalaman belajar bahwa metode ceramah memberi konstribusi 10\% saja. Sehingga hal tersebut menyebabkan hasil belajar belum maksimal. Tampaknya dalam pembelajaran IPS dibutuhkan suatu pola pembelajaran yang mampu menjembatani tercapainya hasil belajar yang maksimal. Kemampuan dan keterampilan guru dalam memilih dan menggunakan metode pembelajaran sangat berpengaruh terhadap hasil belajar anak (Trianto, 2010: 174).

Maka dari itu dalam pencapaian tujuan pembelajaran IPS tersebut, metode pembelajaran sangat penting sebab dengan adanya metode pembelajaran, bahan dapat dengan mudah dipahami oleh peserta didik.

Seperti sekolah lainnya, Madrasah Ibtidaiyah Banjarharja juga sudah menetapkan Kriteria Ketuntasan Minimal (KKM) untuk mata pelajaran IPS di kelas V sebesar 75. Namun kenyataannya yang terjadi di lapangan 


\section{BESTARI}

Vol. 16, No. 2, 2019

p-ISSN 1907-1337; e-ISSN 2807-6532

hasil belajar IPS yang diperoleh peserta didik masih dibawah KKM yaitu dengan rata-rata nilai 72,25 hanya 8 orang yang sudah mencapai KKM dari jumlah 20 orang peserta didik (Sumber: Hasil wawancara dengan wali kelas Madrasah Ibtidaiyah Banjarharja tanggal 6 April 2017).

Menurut Uno (2011: 17) hasil belajar adalah pernyataan yang menunjukkan tentang apa yang mungkin dikerjakan peserta didik sebagai hasil dari kegiatan belajarnya. Jadi hasil belajar merupakan pengalamanpengalaman belajar yang diperoleh peserta didik dalam bentuk kemampuan-kemampuan tertentu.

Hasil belajar di dalam proses pendidikan tidak dapat dilepaskan dari tujuan belajar itu sendiri, artinya hasil belajar merupakan data pembuktian yang akan menunjukkan sampai dimana tingkat kemampuan peserta didik dalam menangkap materi pelajaran.

Melihat permasalahan yang ada maka peneliti memberikan solusi agar pembelajaran IPS dapat disenangi oleh anak dan membuat anak tidak bosan yaitu dengan penggunaan metode pembelajaran yang dapat menunjang hasil belajar IPS. Sehingga dapat mendorong peserta didik aktif, kreatif serta berfikir kritis dalam menyelesaikan persoalanpersoalan yang berkaitan dengan IPS di SD/MI salah satunya adalah dengan menggunakan metode gallery walk. Metode adalah cara yang digunakan untuk mengimplementasikan rencana yang sudah disusun dalam kegiatan nyata agar tujuan yang telah disusun tercapai secara optimal (Syah, 2006: 147).

Penggunaan metode dalam pembelajaran sangat diutamakan guna menimbulkan gairah belajar, motivasi belajar, dan merangsang peserta didik berperan aktif dalam proses pembelajaran, selain itu juga dapat mengajarkan peserta didik dalam pemecahan masalah, terutama pemecahan masalah dalam kehidupan sehari-hari.

Pengembangan metode pembelajaran tersebut sangat perlu dilakukan untuk menjawab kebutuhan keterampilan pemecahan permasalahan yang harus dimiliki oleh peserta didik. Menurut Silberman (2006: 274) metode gallery walk/ galeri belajar merupakan suatu cara untuk menilai dan mengingat apa yang telah siswa pelajari selama berlangsungnya pembelajaran. Metode ini juga sebagai salah satu pembelajaran aktif (PAIKEM) sebagai metode alternatif yang dapat digunakan oleh guru untuk mendorong keaktifan peserta didik baik secara individu maupun kelompok. Metode ini di gunakan dalam proses interaksi belajar dalam mengimplementasikan pembelajaran active learning.

Melalui metode pembelajaran gallery walk diharapkan dapat lebih mempermudah pemahaman materi pelajaran yang diberikan dan 
nantinya dapat mempertinggi kualitas proses pembelajaran yang selanjutnya dapat meningkatkan hasil belajar peserta didik.

Dengan demikian, masalah pokok dalam penelitian ini, yaitu : Bagaimanakah peningkatan hasil belajar peserta didik pada mata pelajaran IPS pokok bahasan proklamasi kemerdekaan dengan menggunakan metode pembelajaran gallery walk di kelas Madrasah Ibtidaiyah Banjarharja Kecamatan Kalipucang Kabupaten Pangandaran?

\section{KAJIAN TEORI}

\section{Pembelajaran IPS SD/MI}

Istilah Ilmu Pengetahuan Sosial (IPS) merupakan program pendidikan yang berupaya mengambangkan pemahaman peserta didik tentang bagaimana manusia sebagai individu dan kelompok hidup bersama dan berinteraksi dengan lingkungannya baik fisik maupun sosial.

Kajian dalam pembelajaran IPS menurut Suradisastra (1993: 4) yaitu tentang manusia, masyarakat dan dunia sekelilingnya, serta hubungan antar manusia dengan latar kehidupan nyata manusia.

Pembelajaran IPS adalah bidang studi yang menghormati, mempelajari, mengolah, dan membahas hal-hal yang berhubungan dengan masalah-masalah human relationship hingga benar-benar dipahami dan diperoleh pemecahannya.

IPS adalah suatu bahan kajian terpadu sebagai penyederhanaan, adaptasi, seleksi dan modifikasi yang diorganisasikan dari konsep-konsep dan keterampilan sejarah, geografi, sosiologi, antropologi, dan ekonomi (Mulyasa, 2002: 194).

Pembelajaran IPS SD/MI lebih menekankan pada aspek "pendidikan" daripada "transfer konsep", karena dalam pembelajaran pendidikan IPS peserta didik diharapkan memperoleh pemahaman terhadap sejumlah konsep dan mengembangkan serta melatih sikap, nilai, moral, dan keterampilannya berdasarkan konsep yang telah dimilikinya. Martorella (1987) (dalam Solihatin \& Rahardjo, 2009: 14).

Pembelajaran IPS SD/MI merupakan serangkaian kegiatan pembelajaran di sekolah yang mempelajari isu-isu sosial yang berkembang di masyarakat yang memuat keadaan geografis, perkembangan sejarah dan kegiatan ekonomi masyarakat.

Berdasarkan Kurikulum Tingkat Satuan Pendidikan (KTSP) 2006 pada jenjang SD/MI mata pelajaran IPS memuat materi Geografi, Sejarah, Sosiologi, dan Ekonomi. Melalui mata pelajaran IPS, peserta didik diarahkan untuk dapat menjadi warga negara Indonesia yang demokratis, dan bertanggung jawab, serta warga dunia yang cinta damai. 


\section{BESTARI}

Vol. 16, No. 2, 2019

p-ISSN 1907-1337; e-ISSN 2807-6532

Di masa yang akan datang peserta didik akan menghadapi tantangan berat karena kehidupan masyarakat global selalu mengalami perubahan setiap saat. Oleh karena itu mata pelajaran IPS dirancang untuk mengembangkan pengetahuan, pemahaman, dan kemampuan analisis terhadap kondisi sosial masyarakat dalam memasuki kehidupan bermasyarakat yang dinamis.

Gunawan (2011: 39) menyatakan bahwa: "IPS merupakan salah satu mata pelajaran yang diberikan di SD yang mengkaji seperangkat peristiwa, fakta, konsep, dan generalisasi yang berkaitan dengan isu sosial". Ilmu pengetahuan sosial sebagai mata pelajaran tidak semata membekali ilmu saja lebih dari itu membekali juga sikap atau nilai dan keterampilan dalam hidup bermasyarakat sehingga mereka mengetahui benar lingkungan, masyarakat dan bangsanya dengan berbagai karakteristiknya.

Dengan demikian, IPS sebagai suatu mata pelajaran di SD/MI bertolak dari kondisi nyata di masyarakat dengan tujuan untuk memanusiakan manusia (peserta didik) melalui hubungan seluruh aspek manusia agar mereka tidak merasa asing dilingkungan masyarakatnya sendiri.

Dalam pedoman penyusunan KTSP SD/MI bahwa mata pelajaran IPS disusun secara sistematis, komprehensif, dan terpadu dalam proses pembelajaran menuju kedewasaan dan keberhasilan dalam kehidupan di masyarakat. Dengan pendekatan tersebut diharapkan peserta didik akan memperoleh pemahaman yang lebih luas dan mendalam pada bidang ilmu yang berkaitan.

Jadi, dapat disimpulkan bahwa pembelajaran IPS SD/MI mengkaji seperangkat peristiwa, fakta, konsep, dan generalisasi yang berkaitan dengan isu sosial, memuat materi geografi, sejarah, sosiologi, dan ekonomi. Sistem pengajarannya menelaah dan mengkaji gejala atau masalah sosial dan berbagai aspek kehidupan sosial, serta pelajaran IPS dirancang untuk mengembangkan pengetahuan, pemahaman, dan kemampuan analisis terhadap kondisi sosial masyarakat dalam memasuki kehidupan bermasyarakat yang dinamis.

IPS merupakan salah satu mata pelajaran yang ada di sekolah dasar. Setiap mata pelajaran memiliki ruang lingkup yang berbeda-beda. Ruang lingkup dalam pembelajaran dapat dijadikan sebagai pembatas dalam menyampaikan materi pembelajaran.

IPS mempelajari, menelaah, dan mengkaji sistem kehidupan manusia di permukaan bumi ini dalam konteks sosialnya atau manusia sebagai anggota masyarakat. Dengan pertimbangan bahwa manusia dalam konteks sosial demikian luas, pengajaran IPS pada jenjang pendidikan harus dibatasi sesuai dengan kemampuan peserta didik tiap 
jenjang, sehingga ruang lingkup pengajaran IPS pada jenjang pendidikan dasar berbeda dengan jenjang pendidikan menengah dan pendidikan tinggi. Pada jenjang pendidikan dasar, ruang lingkup pengajaran IPS dibatasi sampai pada gejala dan masalah sosial yang dapat dijangkau pada geografi dan sejarah. Terutama gejala dan masalah sosial kehidupan sehari-hari yang ada di lingkungan sekitar peserta didik MI/SD.

(Massofa.wordpress.com/2010/12/o9/pengertian-ruang-lingkupdan-tujuan-ips/).

Gunawan (2011: 39) menyebutkan ruang lingkup IPS SD/MI meliputi aspek-aspek sebagai berikut:

1. Manusia, tempat, dan lingkungan.

2. Waktu, keberlanjutan, dan perubahan.

3. Sistem sosial dan budaya.

4. Perilaku ekonomi dan kesejahteraan.

5. IPS SD sebagai pendidikan global (global education), yakni mendidik peserta didik akan kebhinekaan bangsa, budaya, dan peradaban di dunia; menanamkan kesadaran ketergantungan antar bangsa; menanamkan kesadaran semakin terbukanya komunikasi dan transportasi antar bangsa di dunia; mengurangi kemiskinan, kebodohan dan perusakan lingkungan.

Kurikulum 2006 menjelaskan ruang lingkup mata pelajaran IPS meliputi: (1) manusia, tempat, dan lingkungan, (2) waktu, keberlanjutan, dan perubahan, (3) sistem sosial dan budaya, (4) perilaku ekonomi dan kesejahteraan. Dengan adanya ruang lingkup, diharapkan guru dalam menyampaikan materi disesuaikan dengan jenjang pendidikan anak.

Setiap pembelajaran memiliki tujuan yang akan dicapai dalam kegiatan pembelajaran. Dengan adanya tujuan pembelajaran dapat dijadikan sebagai arah untuk mencapai tujuan yang diharapkan dalam proses belajar mengajar. Secara umum, tujuan pembelajaran IPS SD/MI harus sesuai dengan tujuan pendidikan nasional pasal 3 UU No. 20 tahun 2003 tentang Sistem Pendidikan Nasional, yaitu: "Pendidikan nasional berfungsi mengembangkan kemampuan dan membentuk watak serta peradaban yang bermartabat dalam rangka mencerdaskan kehidupan bangsa, bertujuan untuk berkembangnya potensi siswa agar menjadi manusia yang beriman dan bertakwa kepada Tuhan Yang Maha Esa, berakhlak mulia, sehat, berilmu, cakap, kreatif, mandiri, dan menjadi warga negara yang demokratis serta bertanggungjawab.” (Depdiknas, 2006: 13)

Tujuan pembelajaran IPS SD/MI harus diselaraskan dan disesuaikan dengan tujuan pendidikan nasional. Mata pelajaran IPS merupakan salah satu mata pelajaran yang mengarahkan siswa agar menjadi warga negara yang demokratis, bertanggungjawab, serta warga dunia yang cinta damai. 


\section{BESTARI}

Vol. 16, No. 2, 2019

p-ISSN 1907-1337; e-ISSN 2807-6532

Tujuan pendidikan IPS adalah untuk mempersiapkan peserta didik menjadi warga negara yang baik dalam kehidupannya di lingkungan dan mengembangkan kemampuan menggunakan penalaran dalam mengambil suatu keputusan setiap persoalan yang dihadapinya (Gross, 1978) (dalam Solihatin \& Rahardjo, 2009 :14).

Berdasarkan Kurikulum Tingkat Satuan Pendidikan (KTSP) SD/ MI Tahun 2006 mata pelajaran IPS bertujuan agar peserta didik memiliki kemampuan sebagai berikut:

1) Mengenal konsep-konsep yang berkaitan dengan kehidupan masyarakat dan lingkungannya.

2) Memiliki kemampuan dasar untuk berpikir logis dan kritis, rasa ingin tahu, inquiri, memecahkan masalah, dan keterampilan dalam kehidupan sosial.

3) Memiliki komitmen dan kesadaran terhadap nilai-nilai sosial dan kemanusiaan.

4) Memiliki kemampuan berkomunikasi, bekerja sama, dan berkompetisi dalam masyarakat yang majemuk, di tingkat lokal, nasional, dan global.

Berdasarkan beberapa pendapat para ahli, dapat disimpulkan bahwa pembelajaran IPS bertujuan untuk mendidik dan membekali peserta didik agar dapat mengembangkan kemampuan diri yang dimiliki oleh peserta didik sehingga dapat diterapkan di dalam kehidupannya. Dalam pembelajaran IPS diharapkan guru dapat mendidik dan memberi bekal kepada peserta didik dengan pengetahuan dan keterampilan agar dapat bermanfaat bagi kehidupannya.

\section{Konsep Hasil Belajar}

Hasil belajar tidak dapat dipisahkan dari proses belajar. Karena belajar merupakan suatu proses, sedangkan prestasi belajar adalah hasil dari proses pembelajaran tersebut. Bagi seorang peserta didik belajar merupakan suatu kewajiban. Berhasil atau tidaknya seorang peserta didik dalam pendidikan tergantung pada proses belajar yang dialami oleh peserta didik tersebut.

Hasil belajar merupakan bagian terpenting dalam pembelajaran. Nana Sudjana (2009: 3) mendefinisikan hasil belajar peserta didik pada hakikatnya adalah perubahan tingkah laku sebagai hasil belajar dalam pengertian yang lebih luas mencakup bidang kognitif, afektif, dan psikomotorik. Dimyati \& Mudjiono (2006: 3-4) juga menyebutkan hasil belajar merupakan hasil dari suatu interaksi tindak belajar dan tindak mengajar. Dari sisi guru, tindak mengajar diakhiri dengan proses evaluasi hasil belajar. Dari sisi peserta didik, hasil belajar merupakan berakhirnya pengajaran dari puncak proses belajar. 
Hasil belajar adalah pernyataan yang menunjukkan tentang apa yang mungkin dikerjakan peserta didik sebagai hasil dari kegiatan belajarnya. Jadi hasil belajar merupakan pengalaman-pengalaman belajar yang diperoleh peserta didik dalam bentuk kemampuan-kemampuan tertentu (Uno, 2011: 17).

Menurut Bloom dan Kratwohl (dalam Angkowo \& Kosasih, 2007: 53) hasil belajar merupakan perubahan tingkah laku yang secara umum dapat dikelompokkan ke dalam tiga kategori yaitu ranah kognitif, afektif, dan psikomotor.

Dari definisi diatas, maka dapat diambil kesimpulan bahwa hasil belajar adalah prestasi belajar yang dicapai peserta didik dalam proses kegiatan belajar mengajar dengan membawa suatu perubahan dan pembentukan tingkah laku seseorang. Hasil belajar adalah kemampuankemampuan yang dimiliki peserta didik setelah menerima pengalaman belajarnya. Kemampuan-kemampuan tersebut mencakup aspek kognitif, afektif, dan psikomotorik. Hasil belajar dapat dilihat melalui kegiatan evaluasi yang bertujuan untuk mendapatkan data pembuktian yang akan menunjukkan tingkat kemampuan peserta didik dalam mencapai tujuan pembelajaran.

Hasil belajar peserta didik dipengaruhi oleh dua faktor utama yakni faktor dari dalam diri peserta didik dan faktor yang datang dari luar diri peserta didik atau faktor lingkungan. Faktor dari dalam diri peserta didik terutama menyangkut kemampuan yang dimiliki peserta didik. Faktor ini besar sekali pengaruhnya terhadap hasil belajar yang akan dicapai.

Clark (dalam Angkowo \& Kosasih, 2007: 50) mengungkapkan bahwa hasil belajar peserta didik di sekolah 70\% dipengaruhi oleh kemampuan peserta didik dan 30\% dipengaruhi oleh lingkungan.

Berkaitan dengan faktor dari dalam diri peserta didik, selain faktor kemampuan, ada juga faktor lain yaitu motivasi, minat, perhatian, sikap, kebiasaan belajar, ketekunan, kondisi sosial ekonomi, kondisi fisik dan psikis. Salah satu faktor lingkungan yang paling dominan mempengaruhi hasil belajar adalah kualitas pengajaran. Yang dimaksud dengan kualitas pengajaran adalah tinggi rendahnya atau efektif tidaknya proses pembelajaran dalam mencapai tujuan instruksional. Pendapat ini sejalan dengan teori belajar di sekolah (Theory of school learning) dari Bloom, bahwa ada 3 (tiga) variable utama dalam teori belajar di sekolah, yaitu karakteristik individu, kualitas pengajaran, dan hasil belajar peserta didik (Angkowo \& Kosasih, 2007: 50-51).

Selain faktor dari dalam diri dan faktor lingkungan, ada faktor lain yang turut menentukan hasil belajar peserta didik yaitu faktor pendekatan belajar (approach to learning). Ini berkaitan dengan upaya belajar yang dilakukan peserta didik yang meliputi strategi dan metode pembelajaran. Ketiga faktor ini dalam banyak hal saling berkaitan dan 


\section{BESTARI}

Vol. 16, No. 2, 2019

p-ISSN 1907-1337; e-ISSN 2807-6532

saling mempengaruhi satu dengan yang lain (Angkowo \&Kosasih, 2007: 51).

Caroll (dalam Angkowo \&Kosasih, 2007: 51) berpendapat bahwa hasil belajar peserta didik dipengaruhi oleh 5 (lima) faktor yakni:

1) Faktor bakat belajar;

2) Faktor waktu yang tersedia untuk belajar;

3) Faktor kemampuan individu;

4) Faktor kualitas pengajaran;

5) Faktor lingkungan.

Dari kelima faktor tersebut, faktor pertama sampai faktor keempat berkenaan dengan kemampuan individu, sedangkan faktor terakhir merupakan faktor yang datangnya dari luar diri peserta didik yaitu faktor lingkungan.

Faktor-faktor di atas dalam banyak hal sering saling berkaitan dan mempengaruhi satu sama lain. Peserta didik yang bersikap conserving terhadap ilmu pengetahuan atau bermotif ekstrinsik (faktor eksternal) biasanya cenderung mengambil pendekatan belajar yang sederhana dan tidak mendalam.

Jadi, karena pengaruh faktor-faktor tersebut di ataslah, muncul peserta didik yang high achievers (berprestasi tinggi) dan under achievers (berprestasi rendah) atau gagal sama sekali. Dalam hal ini, seorang guru yang kompeten dan professional diharapkan mampu mengantisipasi kemungkinan-kemungkinan munculnya kelompok peserta didik yang menunjukkan gejala kegagalan dengan berusaha mengetahui dan mengatasi faktor yang menghambat proses belajar mereka.

Adapun faktor yang mempengaruhi hasil belajar menurut Komsiyah (2012: 89) diantaranya:

\section{a) Faktor Internal}

(1) Faktor Fisiologis

Secara umum kondisi fisiologis, seperti kesehatan yang prima, tidak dalam keadaan lelah dan capek, tidak dalam keadaan cacat jasmani, dan sebaianya, semuanya akan membantu dalam proses dan hasil belajar. Peserta didik yang kurang gizi misalnya, ternyata kemampuan belajarnya berada di bawah peserta didik yang tidak kekurangan gizi, sebab mereka yang kekurangan gizi pada umumnya cenderung cepat lelah dan capek, cepat ngantuk dan akhirnya tidak mudah dalam menerima pelajaran.

(2) Faktor psikologis

Faktor kedua dari faktor internal adalah faktor psikologis. Setiap manusia atau anak didik pada dasarnya memiliki kondisi psikologi yang 
berbeda-beda. Dengan perbedaan ini, maka akan berpengaruh pada hasil belajar masing-masing. Beberapa faktor psikologis yang dapat di uraikan diantaranya meliputi intelegensi, perhatian, minat dan bakat, motif dan motivasi, kognitif dan daya nalar.

b) Faktor Eksternal

(1) Faktor Lingkungan

Kondisi lingkungan juga mempengaruhi hasil belajar. Lingkungan ini dapat berupa lingkungan fisik atau alam dan dapat pula berupa lingkungan sosial. Lingkungan alam misalnya keadaan suhu, kelembaban, kepengapan udara, dan sebagainya. Sedangkan lingkungan sosial baik yang berwujud manusia maupun hal-hal lainnya. Seperti halnya keluarga, sekolah, masyarakat, dan lingkungan sekitar.

\section{(2) Faktor Instrumental}

Faktor-faktor instrumental adalah faktor yang keberadaan dan penggunaannya dirancang sesuai dengan hasil belajar yang di harapkan. Faktor-faktor ini di harapkan dapat berfungsi sebagai sarana untuk tercapainya tujuan-tujuan belajar yang telah di rencanakan. Faktor instrumental ini dapat berupa kurikulum, saran dan fasilitas, dan guru.

\section{Konsep Metode Gallery Walk}

Gallery walk terdiri dari dua kata, yaitu gallery dan walk. Gallery adalah pameran. Pameran merupakan kegiatan untuk memperkenalkan produk, karya atau gagasan kepada khalayak ramai. Misalnya, tulisan, lukisan dan sebagainya. Sedangkan walk artinya berjalan, melangkah (Ismail, 2008: 274).

Menurut Silberman (2006: 274) metode gallery walk / galeri belajar merupakan suatu cara untuk menilai dan mengingat apa yang telah peserta didik pelajari selama berlangsungnya pembelajaran.

Machmudah \& Rosyidi (2008: 152) menyebut gallery walk dengan sebutan galeri belajar. Galeri belajar merupakan suatu cara untuk menilai dan mengingat apa yang telah peserta didik pelajari.

Gallery walk atau galeri belajar merupakan suatu metode pembelajaran yang mampu meningkatkan kemampuan peserta didik untuk menemukan pengetahuan baru dan dapat mempermudah daya ingat, karena sesuatu yang ditemukan itu dilihat secara langsung. Gallery walk (pameran berjalan) juga dapat memotivasi keaktifan peserta didik dalam proses belajar. Sebab bila sesuatu yang ditemukan itu berbeda antara yang satu dengan yang lain maka dapat saling mengoreksi antara sesama peserta didik baik kelompok maupun antar peserta didik itu sendiri.

Dengan menggunakan metode gallery walk (galeri belajar) diharapkan dapat mengatasi kendala materi pembelajaran yang sulit 


\section{BESTARI}

Vol. 16, No. 2, 2019

p-ISSN 1907-1337; e-ISSN 2807-6532

diserap oleh peserta didik secara tidak maksimal. Sehingga hasil belajar peserta didik pun belum maksimal, karena metode ini dapat menghemat efisiensi waktu pelajaran, dan peserta didik dapat lebih mudah memahami pelajaran karena metode ini memberikan kesempatan kepada peserta didik untuk membuat suatu karya dan melihat langsung kekurang pahamannya dengan materi tersebut dengan melihat hasil karya teman yang lainnya dan dapat saling mengisi kekurangannya itu (Ismail, 2008: 89).

Metode gallery walk memiliki beberapa kelebihan dan kekurangan, beberapa kelebihannya yaitu sebagai berikut:

1) Peserta didik terbiasa membangun budaya kerjasama memecahkan masalah dalam belajar

2) Adanya sinergi saling menguatkan pemahaman terhadap tujuan pembelajaran

3) Membiasakan peserta didik bersikap menghargai dan mengapresiasi hasil belajar kawannya

4) Mengaktifkan fisik dan mental peserta didik selama proses pembelajaran

5) Membiasakan peserta didik memberi dan menerima kritik

6) Peserta didik tidak selalu bergantung kepada guru, sehingga membantu menambah kepercayaan kemampuan berpikir sendiri, menemukan informasi dari berbagai sumber, dan belajar dari sesama peserta didik.

7) Sedangkan kekurangan metode pembelajaran gallery walk yaitu sebagai berikut:

8) Bila anggota kelompok terlalu banyak akan terjadi sebagian peserta didik menggantungkan kerja kawannya

9) Guru perlu ekstra cermat dalam memantau dan menilai keaktifan peserta didik secara individu maupun kelompok

10) Pengaturan setting kelas yang lebih rumit

11) Dalam upaya mengembangkan kesadaran kelompok memerlukan periode waktu yang cukup panjang (www.unhas.ac.id/arab/data_fl/JURNAL _ Marini.docx diakses pada tanggal 4 Maret 2017).

Metode gallery walk dapat digunakan untuk pelaksanaan evaluasi atau berupa ujian. Dalam pelaksanaannya, metode ini membentuk peserta didik menjadi berkelompok, sehingga dapat membantu peserta didik yang memiliki kemampuan rendah karena dibantu oleh peserta didik yang berkemampuan tinggi.

Berikut langkah-langkah pembelajaran menggunakan metode gallery walk menurut Silberman (2006: 264):

1) Guru membagi peserta didik menjadi beberapa kelompok yang beranggotakan tiga sampai lima orang. 
2) Guru memberikan karton/kertas plano kepada setiap kelompok.

3) Menentukan tema atau topik pembelajaran.

4) Menginstruksikan setiap kelompok untuk mendiskusikan apa yang didapatkan dari pembelajaran yang telah diikuti dan membuat daftar pertanyaan.

5) Menginstruksikan kepada setiap kelompok untuk membuat sebuah daftar pada kertas plano yang telah diberikan yang berisi hasil pembelajaran dan harus diberi identitas.

6) Setiap kelompok diintruksikan untuk menempel hasil kerjanya disekitar kelas.

7) Setiap kelompok diintruksikan untuk berputar mengelilingi kelas untuk menilai hasil kerja kelompok lain dan menjawab pertanyaan yang tersedia.

8) Secara bersama-sama mengoreksi hasil kerja orang lain.

\section{METODE PENELITIAN}

Metode penelitian yang digunakan adalah metode Penelitian Tindakan Kelas (PTK) model Kurt Lewin. Teknik pengumpulan data adalah teknik observasi, teknik tes dan penilaian, dan teknik analisis deskriptif. Penelitian ini bertujuan untuk meningkatkan hasil belajar peserta didik pada mata pelajaran IPS pokok bahasan proklamasi kemerdekaan. Penelitian Tindakan Kelas di kelas Madrasah Ibtidaiyah Banjarharja Kecamatan Kalipucang Kabupaten Pangandaran.

\section{HASIL PENELITIAN DAN PEMBAHASAN}

Dari kegiatan yang dilakukan pada siklus I yaitu guru belum terlalu mampu menyusun RPP dengan menggunakan metode pembelajaran gallery walk. Hal ini diperoleh dari hasil pengamatan terhadap kemampuan guru dalam menyusun RPP baru mencapai nilai rata-rata 81,17 dari skor ideal $100 \%$. Kendala yang dihadapi pada siklus I yaitu peserta didik belum terbiasa dengan kondisi belajar baru, langkahlangkah kegiatan pembelajaran kurang tersusun rapi yang mengakibatkan peserta didik kurang memahami intruksi guru.

Dari hasil tes akhir peserta didik siklus I diperoleh hasil belajar peserta didik mencapai nilai rata-rata 79 dengan presentase ketuntasan $65 \%$ yang berarti 13 orang peserta didik yang telah mencapai nilai KKM dari jumlah 20 orang peserta didik.

Pada siklus II guru sudah mampu menyusun RPP yang menggambarkan metode pembelajaran gallery walk. Hal ini diperoleh dari hasil pengamatan terhadap kemampuan guru dalam menyusun RPP mencapai nilai rata-rata 81,56 . 


\section{BESTARI}

Vol. 16, No. 2, 2019

p-ISSN 1907-1337; e-ISSN 2807-6532

Pelaksanaan pembelajaran pada siklus II guru mengalami peningkatan dalam pelaksanaan pembelajaran, ini terlihat dari hasil pengamatan terhadap penilaian kemampuan guru dalam mengajar yang mencapai nilai rata-rata 83,50. Namun dalam hal ini masih ada kekurangan diantaranya siswa belum terbiasa mengajukan pertanyaan, bertanya jawab dengan guru mengenai materi pembelajaran dan dalam mengkondisikan kelas supaya lebih kondusif.

Dari hasil tes akhir peserta didik diperoleh nilai hasil belajar peserta didik mencapai nilai rata-rata 83,25 dengan presentase ketuntasan $80 \%$ yang berarti, 16 orang peserta didik yang telah mencapai nilai KKM dari jumlah 20 orang peserta didik. Berdasarkan hasil tersebut maka hasil tes akhir nilai peserta didik mengalami peningkatan dari siklus I.

Pada siklus III, guru sudah mampu menyusun RPP dengan menggunakan metode pembelajaran gallery walk. Hal ini diperoleh dari hasil observasi terhadap kemampuan guru dalam menyusun RPP mencapai nilai rata-rata 91,17. Pelaksanaan pembelajaran siklus III guru mengalami peningkatan dalam proses belajar mengajar, ini terlihat dari observasi penilaian kemampuan mengajar guru yang mencapai nilai ratarata 92,18 .

Dari hasil evaluasi tes akhir, peserta didik mengalami peningkatan hasil belajar mencapai nilai rata-rata 89,75 dengan presentase ketuntasan $100 \%$ yang berarti, semua peserta didik telah mencapai nilai diatas KKM yang ditentukan.

Maka hal ini dalam proses pembelajaran IPS melalui metode pembelajaran gallery walk di kelas Madrasah Ibtidaiyah Banjarharja Kecamatan Kalipucang Kabupaten Pangandaran sudah baik dan dapat meningkatkan hasil belajar peserta didik mencapai hasil nilai rata-rata diatas KKM yaitu 75. Hal ini dapat dilihat dari rekapitulasi grafik sebagai berikut:

Grafik peningkatan hasil dari siklus 1 sampai siklus 3 


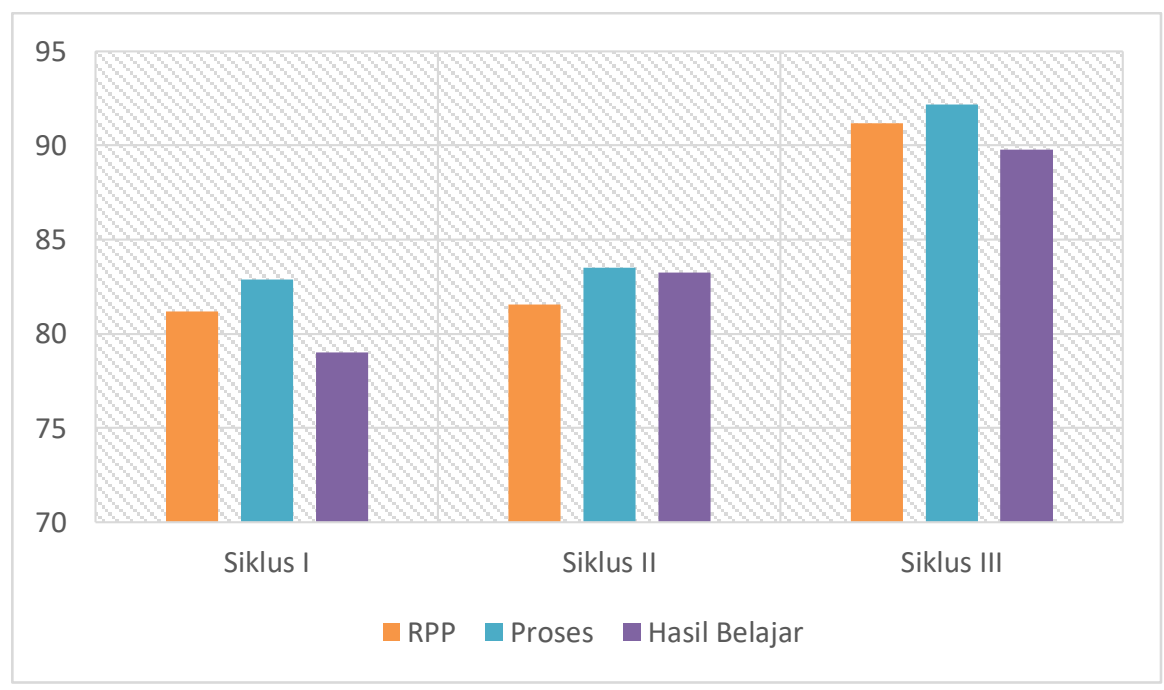

Dari grafik rekapitulasi antar siklus tersebut maka dapat disimpulkan bahwa penerapan metode pembelajaran gallery walk dalam upaya meningkatkan hasil belajar peserta didik pada mata pelajaran IPS pokok bahasan proklamasi kemerdekaan dikatakan berhasil.

\section{KESIMPULAN}

Berdasarkan hasil penelitian tindakan kelas yang dilakukan penelitian pada pembelajaran IPS pokok bahasan Proklamasi Kemerdekaan dengan menggunakan metode pembelajaran gallery walk yang dilaksanakan di kelas Madrasah Ibtidaiyah Banjarharja Kecamatan Kalipucang Kabupaten Pangandaran, maka peneliti menyimpulkan halhal sebagai berikut: (1) Perencanaan pembelajaran IPS pokok bahasan proklamasi kemerdekaan menggunakan metode gallery walk di kelas Madrasah Ibtidaiyah Banjarharja Kecamatan Kalipucang Kabupaten Pangandaran yang dilakukan oleh guru telah sesuai dengan acuan standar KTSP, dan mengalami peningkatan setiap siklusnya. Hal ini dapat dilihat dari hasil observasi perencanaan pembelajaran pada siklus I mencapai nilai rata-rata 81,17 (baik) sedangkan pada siklus II mencapai nilai ratarata 81,56 (baik) dan pada siklus III mencapai nilai rata-rata 91,17 (sangat baik). (2) Pelaksanaan pembelajaran IPS pokok bahasan proklamasi kemerdekaan dengan menggunakan metode pembelajaran gallery walk di kelas Madrasah Ibtidaiyah Banjarharja Kecamatan Kalipucang Kabupaten Pangandaran yang dilakukan oleh guru telah menunjukkan kegiatan pembelajaran yang mengacu pada pembelajaran aktif, inovatif, kreatif, efektif, dan menyenangkan. Kemampuan guru dalam melaksanakan pembelajaran terus mengalami peningkatan dari siklus ke siklus. Hal tersebut dapat dilihat dari hasil observasi pada siklus I kemampuan guru mencapai 82,87 (baik) sedangkan pada siklus II mencapai nilai rata-rata 83,50 (baik) dan pada siklus III mencapai nilai 


\section{BESTARI}

Vol. 16, No. 2, 2019

p-ISSN 1907-1337; e-ISSN 2807-6532

rata-rata 92,18 (sangat baik). (3) Hasil belajar peserta didik kelas Madrasah Ibtidaiyah Banjarharja Kecamatan Kalipucang Kabupaten Pangandaran setelah mengikuti pembelajaran IPS pokok bahasan proklamasi kemerdekaan mengalami peningkatan dari siklus ke siklus. Hal itu dapat dilihat dari nilai tes pada siklus I mencapai nilai rata-rata 79 (baik) dengan presentase ketuntasan 65\% sedangkan pada siklus II mencapai nilai rata-rata 83,25 (baik) dengan presentase ketuntasan $80 \%$ dan pada siklus III mencapai nilai rata-rata 89,75 (baik) dengan presentase ketuntasan 100\%.

\section{DAFTAR PUSTAKA}

Angkowo \& Kosasih, (2007). Optimalisasi Media Pembelajaran. Jakarta: PT Grasindo.

Depdiknas. (2006). Panduan Kurikulum Tingkat Satuan Pendidikan $S D / M I$. Jakarta: Depdiknas.

Dimyati \& Mudjiono. (2006). Belajar dan Pembelajaran. Jakarta: PT Rineka Cipta.

Gunawan, Rudy. (2011). Pendidikan IPS. Bandung: Alfabeta.

Komsiyah, Indah. (2012). Belajar dan Pembelajaran. Yogyakarta: Teras.

Machmudah, U. \& Rosyidi, A.W. (2008). Active Learning Dalam Pembelajaran Bahasa Arab. Yogyakarta : Sukses Offset.

Sapriya. (2002). Praktek Penelitian Tindakan Kelas. Bandung: Remaja Rosdakarya.

. (2006). Konsep Dasar IPS. Bandung : UPI PRESS.

Silberman, Melvin L. (2006). 101 Strategi Pembelajaran Aktif. Yogjakarta : Pustaka Insan Madani.

Solihatin \& Rahardjo. (2009). Cooperative Learning Analisis Model Pembelajaran IPS. Jakarta: Bumi Aksara.

Suradisastra, Djodjo. (1993). Mata Pelajaran IPS di SD. Jakarta: Kencana.

Syah, Muhibbin. (2006). Psikologi Pendidikan dengan Pendekatan Baru. Jakarta: Prenada Media Group.

Trianto. (2010). Model Pembelajaran Terpadu. Jakarta : PT Bumi Aksara.

Uno, Hamzah B. (2011). Model Pembelajaran Menciptakan Proses Belajar Mengajar yang Kreatif dan Efektif. Jakarta: Bumi Aksara. 
Winataputra, Udin S. (2010). Materi dan Pembelajaran IPS SD. Jakarta : Universitas Terbuka.

Marini, Efektifitas Penggunaan Metode Gallery Walk dalam Meningkatkan Siswa pada Pembelajaran Bahasa Arab di Madrasah Tsanawiyah Al-Fatah Tarakan. www.unhas.ac.id/arab/data_fl/JURNAL_ Marini.docx

Massofa.wordpress.com/2010/12/o9/pengertian-ruang-lingkup-dantujuan-ips/ 